\title{
Monitoring Progress Toward Meeting the United Nations SDG on Pre-primary Education: An Important Step Towards More Equitable and Sustainable Economies ${ }^{1}$
}

\author{
N. Milovantseva, A. Earle, J. Heymann
}

Natalia Milovantseva - PhD, Associate Professor, Faculty of World Economy and International Affairs, National Research University Higher School of Economics; 17/1 Malaya Ordynka Str., Moscow, 119017, Russian Federation; E-mail: nmilovantseva@hse.ru

Alison Earle - PhD, Senior Research Scientist at the WORLD Policy Analysis Center at the University of California University, Los Angeles (UCLA); 621 Charles E. Young Dr. South, Los Angeles, CA 90095, USA; E-mail: aearle@ph.ucla.edu

Jody Heymann - MD, PhD, Founding Director of the WORLD Policy Analysis Center, Distinguished Professor of Public Policy at the Luskin School of Public Affairs, of Medicine at the Geffen School of Medicine, and of Health Policy and Management at the Fielding School of Public Health at UCLA; 621 Charles E. Young Dr. South, Los Angeles, CA 90095, USA; E-mail: jody.heymann@ph.ucla.edu

\begin{abstract}
Despite widespread agreement among international organizations on the importance of healthy early childhood development, monitoring of national action on the provision of pre-primary education has been limited. This paper presents a quantitative approach to monitoring the world's progress on the United Nations (UN) sustainable development goal (SDG) target 4.2 to "ensure that all girls and boys have access to quality early childhood development, care and pre-primary education." A rigorous approach was used to create a new quantitative globally comparable database of indicators for policies that mandate the provision of national pre-primary education for $86 \%$ of UN member states. This dataset was analyzed to examine global inequalities in the provision of universal pre-primary education and revealed that $45 \%$ of countries, and only $15 \%$ of lowincome countries, provide tuition-free pre-primary education. Just under $27 \%$ of countries offer tuition-free pre-primary education for two or more years. This contrasts sharply with primary education, which is provided tuition-free in $96 \%$ of countries. To illustrate how this data can contribute to the examination of the relationship between policy and outcome, it is used in a regression analysis. Additional global data collection on the quality of pre-primary education would further enhance efforts to monitor policies that play key roles in the fulfillment of target 4.2, and support the achievement of the United Nations sustainable development goal on education.
\end{abstract}

Key words: sustainable development goals; quantitative policy data; global educational inequalities; education policy; comparative policy analysis

For citation: Milovantseva N., Earle A., Heymann J. (2018) Monitoring Progress Toward Meeting the United Nations SDG on Pre-primary Education: An Important Step Towards More Equitable and Sustainable Economies. International Organisations Research Journal, vol. 13, no 4, pp. 137-158 (in English). DOI: 10.17323/1996-7845-2018-04-06.

${ }^{1}$ The editorial board received the article in October 2017. 


\section{Introduction}

The adoption of the United Nations (UN) 2030 Agenda for Sustainable Development marks an important shift in the UN's priorities in the area of education. While the millennium development goals (MDGs) focused exclusively on achieving universal primary education, the sustainable development goals (SDGs) emphasize the importance of education before and after primary school. This focus reflects the growing consensus that experiences from birth to age five critically influence long-term outcomes and inequalities. The SDGs highlight the importance of effectively monitoring national policies affecting early childhood development and education, an area that other international organizations, including the World Health Organization and the World Bank among others, have similarly prioritized. The United Nations 2030 Agenda for Sustainable Development also reflects an understanding that in order to achieve the sustainable development goals, results of the monitoring process must be widely disseminated so that nations can improve the effectiveness of their efforts.

The monitoring of progress toward achieving the SDGs and the method for encouraging accountability is referred to in the Agenda as "systematic follow-up and review." Annual monitoring of the indicators has the potential "to serve as a management tool, informing national planning and budgetary processes, as well as global follow-up" [UN, 2015]. The two main outputs of the follow-up and review process are an annual SDG progress report prepared by the secretary general with support of UN agencies, and monitoring report produced by the UN's High-Level Political Forum on Sustainable Development (HLPF).

While the May 2015 Indicators and a Monitoring Framework for the Sustainable Development Goals Report notes that "input or process measures of implementation" sometimes play a critical role in driving the changes needed to achieve improvements in outcomes and may therefore be relevant [Sustainable Development Solutions Network, 2015], there are few direct policy indicators. To make progress on goals that are ambitious and in areas where movement may be incremental, it is important to measure the drivers of change as well as to collect the data needed to enable analysis of which policies lead to change. Tracking the status of laws and policies is valuable because they are directly actionable by policymakers and civil society [Heymann et al., 2013; Atabay et al., 2015; Cassola et al., 2016; Lesnikowski et al., 2016]. Moreover, as described elsewhere, this approach would also enable an assessment of the relationship between policies and outcomes which can range from cross-sectional analysis of national-level data [Earle, Heymann, 2006; Schliwen et al., 2011] to quasi-experimental longitudinal analyses, depending on the data that are available [Daku et al., 2012; Heymann et al., 2013; Hajizadeh et al., 2015; Conklin et al., 2016; Nandi et al., 2016].

Recognizing the role of pre-primary education in building the foundation for sustainable economic development, the UN included in goal 4 of its sustainable development goals target 4.2: "By 2030, ensure that all girls and boys have access to quality early childhood development, care and pre-primary education so that they are ready for pri- 
mary education" [UN, 2015]. The UN's current indicator for target 4.2 is "Percentage of children (36-59 months) receiving at least one year of a quality pre-primary education program." In the case of pre-primary education, while it is important to measure attendance at pre-primary school using enrolment rates per the Global Monitoring Indicators framework, an indicator of national policy stipulating government provision of free and compulsory pre-primary education would be a useful immediate measure of steps taken to advance progress. An approach to monitoring that involves making comparable, quantitative, analyzable data on national policies readily available to policymakers, civil society organizations and citizens on the performance of their own and other countries would increase accountability and transparency, thereby strengthening and complementing the existing "follow up and review" monitoring plan.

\section{Access to Pre-primary Education as a Contributor to Sustainable Development}

A vast literature on early childhood development has established the connection between pre-primary education completion rates and subsequent levels of educational attainment, employment and economic development. A theoretical framework for the critical importance of investing in pre-primary education for a number of further lifelong outcomes has been established through describing the mechanisms such as "skill begets skill" by J.J. Heckman [2000]. Many studies have established that early life experiences have a significant effect on children's cognitive development and learning outcomes later in life [Shonkoff, Phillips, 2000; Heckman, 2006; Knudsen et al., 2006; Grantham-McGregor et al., 2007].

Moreover, research focusing specifically on attendance in pre-primary education in a wide range of countries has consistently found positive effects on subsequent primary school achievements and graduation rates. In a longitudinal study in Argentina, a year of public pre-primary school attendance increased Spanish and mathematics test scores by $23 \%$ of the standard deviation of the distribution of test scores [Berlinski et al., 2009]. Attendance in preschool for at least a year was associated with higher fourth grade test scores in mathematics, reading and social sciences in a cross-sectional study of 159,000 children in Chile [Cortazar, 2015]. Similar results were found in Nepal where at least $95 \%$ of the 935 children who attended various early child development programmes received dramatically better year-end examination scores than children who did not come from such programmes [Save the Children, 2003]. Likewise, studies in Ghana and Cape Verde documented the positive impact of preschool attendance on raw test scores at the end of the programme [Jaramillo, Tietjen, 2001]. Furthermore, a three-year study in rural Bangladesh revealed significantly higher first and second grade primary school achievements by 180 graduates of 30 pre-primary programmes compared to children who did not attend pre-primary school [Aboud, Hossain, 2011]. Strong positive association between preschool completion and decreased grade-repetition rates in primary school were observed in Brazil by a cross-sectional study based 
on national surveys [World Bank, 2001]. In one of the largest studies to date, in $89 \%$ of 65 countries served by the Programme for International Student Assessment (PISA), attending pre-primary school for at least one year raised reading test scores at age 15 controlling for socio-economic background, and the effect was larger for two or more years of pre-primary education [OECD, 2011].

Much evidence is also available showing that pre-primary education especially benefits poor children in both high- and low- to middle-income countries (Havnes, Mogstad [2011] for Norway; Deming [2009] for the U.S.; Dumas, Lefranc [2010] for France; Mingat, Seurat [2011] for Madagascar; Martinez et al. [2012] for Mozambique).

Studies using extensive follow-up data show long-term positive effects. In randomized controlled studies of small-scale programmes in the U.S., researchers have followed children from preschool through adulthood and found higher academic achievement, increased high school graduation rates, lower grade repetition and decreased recommendations for remedial education services [Reynolds et al., 2002; Schweinhart et al., 2005; Barnett, Masse, 2007]. A longitudinal retrospective analysis over five years in Uruguay found a positive effect of pre-primary education attendance. Using a within household sibling comparison methodology, the study found that it reduces the likelihood of early grade repetition and raises overall educational attainment [Berlinski et al., 2008].

This paper assesses how many world economies have a policy in place to support the SDG target 4.2 of ensuring that all children receive at least one year of preprimary education. Drawing on a newly created database of indicators of the provision of tuition-free pre-primary education, the feasibility and utility of this data to assess country action on one of the SDG targets is demonstrated. The status of pre-primary education provision in 163 countries is assessed based on the sources available as of 2015. The availability and duration of free, and free and compulsory pre-primary education globally, and the variation in availability by level of economic development and geographic region are investigated. Next, this article demonstrates how the quantitative data on national policies can be utilized to examine a relationship between policies and outcomes. Analysis of the relationship between pre-primary education provision and rates of enrolment in pre-primary education also provides information about how closely related pre-primary education policy provision is to the indicator for target 4.2, participation/enrolment rates.

The focus is on the provision of free and compulsory pre-primary education because children must enroll in pre-primary education in order to receive its benefits and studies have shown that one of the greatest barriers to enrolment especially among poor families is tuition [Alderman et al., 2001; Kadzamira, Rose, 2003; Hillman, Jenkner, 2004; Princeton University, 2006]. Introducing or increasing fees tends to reduce school enrolment [Burke, Beegle, 2004; Sayre et al., 2014]. For example, in one Nigerian state enrolment in primary school dropped from $90 \%$ to $60 \%$ between 1982 and 1984 after school fees were imposed. At the same time, research from a range of 
countries has found that providing free education tends to raise the number of children enrolled in school [Nielsen, 2009]. Making free pre-primary education compulsory is one of the necessary steps toward its universality.

\section{Methodology}

\section{Data}

To identify which countries have made pre-primary education tuition-free and compulsory, a new global database was created that captures policies on the provision of pre-primary education at a national level. The quantitatively comparable data were primarily created from reviewing and coding national government reports to the United Nations Educational, Scientific and Cultural Organization (UNESCO) International Bureau of Education's World Data on Education database, 6th and 7th Editions, and the 48th International Conference on Education (2008). These reports were used as the main source because they provide comparable qualitative data on the largest number of nations. The reports contain a comprehensive discussion of national educational systems, including descriptions of educational principles, educational laws and basic regulations, administration and management, structure and organization, and educational process. When data were incomplete or unavailable through these sources, they were supplemented with information available through the following sources: World Bank Systems Approach for Better Education Results (SABER) country reports, International Council for Open and Distance Education country profiles, official documentation accessible through Planipolis, a portal of education plans from UNESCO member states, and the Eurypedia, a database of European Union (EU) country education policies. The information in the reports and documents was systematically coded into a set of quantitative variables. To assure comparability, a coding framework was established to capture provision details and allow meaningful comparisons across programmes instituted by different nations. At least two coders separately reviewed sources for each country and compared coding decisions to confirm standard interpretation and to reduce potential for human error or inconsistencies. This followed the rigorous methodology for creating quantitative indicators from detailed educational policy and legal texts used in previous studies [Heymann, 2013; Quamruzzaman et al., 2014; Heymann et al., 2014b].

To increase comparability of policies across countries, the fact that nations refer to pre-primary education using different terms, including early childhood education, nursery school, pre-primary programme, preschool, kindergarten or preparatory school, was taken into account. UNESCO's International Standard Classification of Education (ISCED) definition of pre-primary or level 0 education was used, which is "ISCED level 0 programmes target children below the age of entry into ISCED level 1. There are two categories of ISCED level 0 programmes: early childhood educational development and pre-primary education. The former has educational content designed 
for younger children (in the age range of 0 to 2 years), whilst the latter is designed for children from age 3 years to the start of primary education" [UNESCO, 2012]. If the entrance age to primary school in a country is five, the educational programmes provided for children aged three and four were examined. If the first year of primary education is termed a "reception year" or something similar, it was considered a part of primary education and it was not captured as a pre-primary programme in the dataset. When reports contain pre-primary education policy information on subnational level, the data reflect provisions that apply to the majority of territorial units in the country.

The database includes information on pre-primary education for $86 \% \mathrm{UN}$ member states for which recent data were available in the UNESCO reports or other sources (166 countries; see Table 1). Overall, the distribution of countries by income and region in the descriptive sample is comparable to the income and region distribution for all 192 UN member states (as of 2011). The sample of countries in the regression analysis of pre-primary enrolment are slightly more likely to fall in the high- and middle-income categories.

Table 1. Characteristics of countries used in the analyses by level of income and world region

\begin{tabular}{|l|c|c|c|}
\hline & $\begin{array}{c}\text { Sample in descriptive } \\
\text { analysis } \\
(\boldsymbol{n}=\mathbf{1 6 6}), \boldsymbol{\%}\end{array}$ & $\begin{array}{c}\text { Sample in regres- } \\
\text { sion analysis } \\
(\boldsymbol{n}=\mathbf{1 2 4}), \boldsymbol{\%}\end{array}$ & $\begin{array}{c}\text { UN member } \\
\text { states } \\
(\boldsymbol{n}=\mathbf{1 9 2}), \boldsymbol{\%}\end{array}$ \\
\hline Level of income & 16 & 16 & 18 \\
\hline Low & 29 & 22 & 29 \\
\hline Lower-middle & 28 & 31 & 27 \\
\hline Upper-middle & 27 & 31 & 26 \\
\hline High & & & 18 \\
\hline Geographic region & 19 & 22 & 16 \\
\hline Emericas & 16 & 11 & 28 \\
\hline Europe and Central Asia & 30 & 32 & 10 \\
\hline Middle East and North Africa & 10 & 10 & 4 \\
\hline South Asia & 3 & 2 & 25 \\
\hline Sub-Saharan Africa & 22 & 22 & \\
\hline
\end{tabular}

Note: All percentages are rounded to the nearest whole number. Some percentages may not always sum exactly to $100 \%$ as a result of rounding. National income and regional groupings used are based on 2011 World Bank classifications. Descriptive sample includes all countries with data on pre-primary education policy data from UNESCO or other sources between 2006 and 2015.

Source: compiled by the authors.

National gross domestic product and level of urbanization (as well as income and region) were obtained from the World Bank's World Development Indicators in the same year as the pre-primary enrolment data that was used. 
The data on national enrolment and graduation rates were obtained from the UNESCO Institute of Statistics Data Centre.

\section{Variables}

Countries classified as having free pre-primary education were those countries with a policy in place providing at least one year of pre-primary education, using the UNESCO definition of pre-primary (level 0) education, and charging no tuition or educational fee (although other fees could be charged for such things as meals or field trips).

Countries classified as having compulsory pre-primary education were those countries with a policy mandating at least one year of attendance in pre-primary education, using the UNESCO definition of pre-primary (level 0) education. The number of years of compulsory pre-primary education is a categorical variable containing three categories: zero years, one year and two years or more. SDG target 4.2 is a single year of pre-primary education while at least two years of free pre-primary education "with developmentally appropriate curriculum and classrooms, and quality assurance mechanisms" is the standard in the World Bank SABER framework for early childhood development [Neuman, Devercelli, 2013].

Countries providing free and compulsory pre-primary education were countries where there was a national policy providing at least one year of both free and compulsory pre-primary education. This composite variable was coded as missing if there was missing data for either the indicator of "tuition-free" or "compulsory." The "free and compulsory" variable measures the policy in place irrespective of the degree of implementation or the percentage of the relevant age-eligible population that is enrolled in a pre-school program. Comprehensive data on the degree of implementation are not available at the global level at present. Another variable indicates the number of years that free, compulsory pre-primary education is provided: zero, one year and two years or more.

The net pre-primary enrolment rate is defined as the number of children who are reported to have enrolled in pre-primary school (regardless of age) expressed as a percentage of the number of age-appropriate children in the population. Net enrolment rates were utilized as a commonly used measure of school enrolment: a high net enrolment rate indicates a high degree of coverage for the official school-age population of children. Compared to gross rates, net rates do not include enrolment of under- and over-aged children.

Research suggests that a country's level of national economic development and level of urbanization both strongly influence educational enrolment. For analysis of the relationship between provision of pre-primary education and pre-primary net enrolment rates, countries' per capita gross domestic product (GDP) and urbanization in the year in which enrolment was measured were controlled. Per capita GDP is measured in current U.S. dollars. To account for the difference in the impact of income at the lower and the higher ends of the national income spectrum, the natural logarithm of 
per capita GDP was utilized. Urbanization is defined as the percentage of the population living in an urban area.

Geographic region is based on the World Bank's 2011 classification and includes East Asia and Pacific, Europe and Central Asia, Middle East and North Africa, the Americas, South Asia and Sub-Saharan Africa.

Income/grouping is based on the World Bank's 2011 classification. Countries are classified in one of four income groups: low, lower-middle, upper-middle and high. Income is measured using World Bank estimates of per capita gross national income after converting local currency into U.S. dollars, using the World Bank Atlas method [World Bank, 2016].

\section{Analytic Approach}

Two sets of analyses were conducted. First, the status of pre-primary education provision was described globally, by region and by level of income. The percentage of countries with a national policy guaranteeing tuition-free pre-primary education was calculated, as was the percentage guaranteeing tuition-free and compulsory pre-primary education. In addition, the frequency distribution of the duration of tuition-free (and tuition-free and compulsory) pre-primary education policies was generated.

A linear regression analysis was conducted to examine whether the provision of at least one year of free pre-primary education is associated with pre-primary education enrolment rates. A linear regression model was fitted in which the dependent variable was the national net pre-primary enrolment rate for the most recent available year from 2011 to 2014, and the key predictor variable was an indicator of free pre-primary education provision in the most recent year between 2006 and 2011. The natural logarithm of per capita GDP and the rate of urban population in the year in which enrolment is measured were included as control variables in the model.

\section{Results}

Fewer than half of the countries studied provide at least one year of tuition-free preprimary education, whether compulsory or not (see Table 2). Only $27 \%$ of all the countries studied (45 of 166) provide two or more years of free pre-primary education. Nineteen percent of countries provide tuition-free pre-primary education and also make it compulsory; among these, a minority (39\%) provide it for two years or more. In contrast, among the $26 \%$ of countries that provide free but not compulsory pre-primary education, a majority (76\%) provide it for two or more years.

The provision of pre-primary education varies substantially by region (see Table 3 ). Based on the available data, in Europe and Central Asia $70 \%$ of countries provide at least one year of tuition-free pre-primary education. In the Americas, the percentage is slightly higher at $75 \%$. In comparison, a smaller fraction of countries in South Asia (17\%), Sub-Saharan Africa (14\%), Middle East and North Africa (25\%) and East Asia and the Pacific (19\%) offer at least one year of tuition-free pre-primary school. 
Table 2. Global provision of pre-primary education

\begin{tabular}{|c|c|c|c|c|c|c|c|}
\hline Total & $\begin{array}{l}\text { No tuition-free pre- } \\
\text { primary education }\end{array}$ & \multicolumn{2}{|c|}{$\begin{array}{c}\text { Tuition-free pre- } \\
\text { primary education }\end{array}$} & $\begin{array}{c}\text { Tuition-free and com- } \\
\text { pulsory }\end{array}$ & \multicolumn{2}{c|}{$\begin{array}{c}\text { Tuition-free but not com- } \\
\text { pulsory }\end{array}$} \\
\hline 166 & 92 & \multicolumn{2}{|c|}{74} & \multicolumn{2}{c|}{31} & \multicolumn{2}{|c|}{42} \\
\hline $100 \%$ & $55 \%$ & \multicolumn{2}{|c|}{$45 \%$} & \multicolumn{2}{|c|}{$19 \%$} & \multicolumn{2}{|c|}{$26 \%$} \\
\hline & & 1 year & 2 years & 1 year & 2 years & 1 year & 2 years \\
\hline & & 29 & 45 & 19 & 12 & 10 & 32 \\
\hline & & $39 \%$ & $61 \%$ & $61 \%$ & $39 \%$ & $24 \%$ & $76 \%$ \\
\hline
\end{tabular}

Note: The number of "tuition-free and compulsory" and "tuition-free but not compulsory" countries does not sum to 74 due to lack of data on whether pre-primary education was compulsory for one country. All percentages are rounded to the nearest whole number.

Source: compiled by the authors.

Table 3. Provision of pre-primary education by region

\begin{tabular}{|l|c|c|c|}
\hline & $\begin{array}{c}\text { At least 1 year of } \\
\text { tuition-free pre-prima- } \\
\text { ry education, \% }\end{array}$ & $\begin{array}{c}\text { Two years of tuition- } \\
\text { free pre-primary } \\
\text { education, \% }\end{array}$ & $\begin{array}{c}\text { At least one year of } \\
\text { tuition-free, com- } \\
\text { pulsory pre-primary } \\
\text { education, \% }\end{array}$ \\
\hline Americas & 75 & 38 & 47 \\
\hline East Asia and the Pacific & 19 & 12 & 4 \\
\hline Europe and Central Asia & 70 & 42 & 26 \\
\hline Middle East and North Africa & 25 & 19 & 6 \\
\hline South Asia & 17 & 17 & 0 \\
\hline Sub-Saharan Africa & 14 & 14 & 3 \\
\hline
\end{tabular}

Note: All percentages are rounded to the nearest whole number.

Source: compiled by the authors.

When it comes to providing two years or more of free pre-primary education, the highest prevalence is among countries in Europe and Central Asia (42\%) and the Americas (38\%). These regions also reflect a relatively high prevalence of at least one year of free and compulsory pre-primary education (47\% of countries in the Americas and $26 \%$ in Europe and Central Asia). In all four other regions, the rate for provision of at least one year of tuition-free and the rate for at least one year of free and compulsory education are $25 \%$ or less. In South Asia, there are no countries with tuition-free compulsory pre-primary education. 
In addition to regional differences, there are marked disparities in provision of free pre-primary education across income levels (see Figure 1). Provision of at least one year of free pre-primary education is much more common in high-income $(62 \%)$ and upper-middle-income (63\%) countries than in low-middle-income countries (27\%) and low-income countries (15\%).

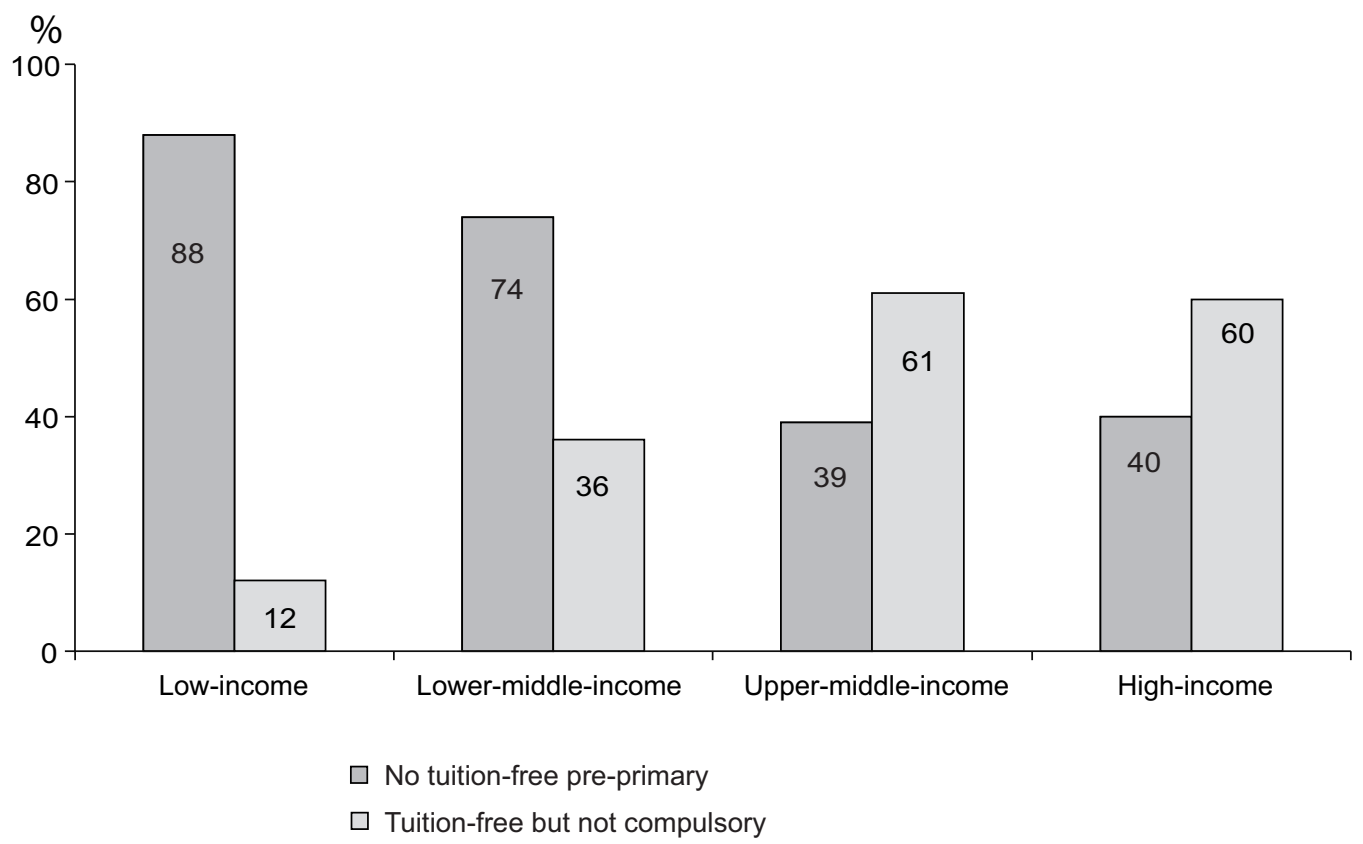

Fig. 1. Percent of countries with and without free pre-primary education, by income level

Source: Compiled by the authors.

There are also marked disparities in the provision of universal or free and compulsory pre-primary school across income levels. A third of the upper-middle-income countries (33\%) but only $15 \%$ of low-middle-income countries provide at least one year of free and compulsory pre-primary education.

Table 4 shows the results of the ordinary least squares (OLS) regression analysis examining the relationship between free pre-primary education provision and pre-primary net enrolment rates. Provision of free pre-primary education, whether compulsory or not, was found to be associated with higher net enrolment rates at the pre-primary level and the relationship was statistically significant. Provision of at least one year of tuition-free pre-primary education was associated with an average increase in net enrolment rates at the pre-primary level of $16 \%$, even after controlling for per capita GDP and urbanicity. 
Table 4. OLS regression model predicting net enrolment rates at pre-primary level

\begin{tabular}{|l|c|}
\hline & $\boldsymbol{\beta}$ \\
\hline At least one year of pre-primary education is free & $16.39^{* * *}$ \\
& $(3.81)$ \\
\hline Natural log of per-capita GDP & $12.13^{* * *}$ \\
& $(1.61)$ \\
\hline Percent of population living in urban area & 0.04 \\
& $(0.11)$ \\
\hline Constant & $-61.69^{* * *}$ \\
& $(10.74)$ \\
\hline$N$ & 124 \\
\hline$R^{2}$ & 0.63 \\
\hline
\end{tabular}

Note: Standard errors are reported in parentheses. For summary statistics see Supplementary Table. ${ }^{*},{ }^{* *},{ }^{* * *}$ refer to $\mathrm{p} \leqslant 0.05, \mathrm{p} \leqslant 0.01$, and $\mathrm{p} \leqslant 0.001$, respectively.

Source: Compiled by the authors.

\section{Discussion}

Despite the widespread agreement across international organizations on the importance of supporting healthy early childhood, monitoring of national action on the provision of pre-primary education has been limited. This paper employs an approach to monitoring national pre-primary education provision based on globally comparable measures of law and policy. The global provision of pre-primary education was evaluated based on the latest policy data available for 166 countries, members of the UN. In addition, regression analyses were employed to examine the association between provision of free pre-primary education and pre-primary net enrolment rates.

Globally, there are substantial gaps in the provision of pre-primary education. Around the world, fewer than half the countries with available data make at least one year of pre-primary education financially accessible by providing tuition-free programmes. Just $27 \%$ of countries examined offer free pre-primary education for two or more years. This study also highlighted substantial variation in the provision of free pre-primary education by national income, which often leaves children in the poorest countries deprived of the opportunity for early learning. Only a small minority of low-income countries provide free pre-primary education. Similar variation exists in the distribution of policies ensuring that pre-primary education is universal. One third of the upper-middle-income countries but only $15 \%$ of low-middle-income countries provide at least one year of free and compulsory pre-primary education.

The analysis also illustrates the global accessibility gap between primary education and pre-primary preparation. As of 2014, 159 countries had made primary education free and compulsory [de Guzman Chorny et al., 2014]. Yet fewer than half (44\%) of the countries that provide free primary education also offer at least one year of free preprimary education as of 2015. 
The analysis also revealed that provision of free pre-primary education was associated with increased pre-primary enrolment rates: availability of at least one year of free pre-primary education was associated with an average increase in enrolment of $16 \%$.

This study's findings should be interpreted with the following limitations in mind. The available and reliable sources described above were systematically analyzed to create the database of pre-primary education policy provision. A measure of the level of implementation could not be incorporated because this information was not provided for all countries (although some sources provided a comprehensive picture of the challenges to full implementation). Because available cross-sectional data was used for the multivariate analysis of pre-primary enrolment rates, the analysis can only establish an association and not a causal relationship between the type of provision and enrolment rates at the pre-primary level. Studies of changes in outcome measures before and after the introduction or removal of pre-primary tuition are needed to demonstrate causation. Data on other potential explanatory variables, such as the availability and role of non-state provided pre-primary programmes, the location and accessibility of pre-primary programmes, as well as the amount of other fees and costs, are also not available currently on a global basis and may contribute to pre-primary enrolment rates.

Also, a binary indicator of provision of public, free and compulsory pre-primary education and a simple measure of years of education provided are broad, high-level indicators of progress and do not address the full scope of SDG target 4 which specifies ensuring access to "quality" education. An important next step thus would be to increase efforts to gather quantitative, comparable data on indicators of policies affecting the quality of pre-primary education on a global basis, including teacher training requirements, age-appropriateness and inclusiveness of curriculum, availability of learning materials, and the quality of school's environment, among others. Evidence on the importance of these indicators - especially teacher training and preparation requirements - to the quality of the programmes and children's outcomes is growing [Sheridan et al., 2009; Mtahabwa, Rao, 2010] but further and more comprehensive, i.e., including all nations globally, assessment requires additional global data.

Also important to consider is the way in which pre-primary education fits within the overall approach to, and can be integrated with, other services for pre-school-age children such as health and nutrition services. There is evidence that multi-sector approaches can be effective at increasing enrolment, and potentially significant gains have been shown for marginalized groups such as disabled and low-income children [World Bank, 2013; Vargas-Baron, 2015; Yoshikawa, Kabay, 2015]. Individual country studies suggest that certain characteristics, e.g. coordination across agencies, staff continuity, extensive consultations with all stakeholders in policy development and strong commitment at the national level, increase the effectiveness of such programmes [Engle et al., 2013; Britto et al., 2014; DiGirolamo et al., 2014; Vargas-Baron, 2015] but without comparison data across the full range of programmes and contexts firm conclusions and recommendations cannot be made. 
This article illustrates the potential for using policy data in monitoring progress towards the SDGs and in assessing the relationship of policy steps to outcomes using one target - universal access to pre-primary education - as an example. This builds on previous proposals to use policy indicators to monitor global human rights agreements [Heymann et al., 2014a, 2015; Raub et al., 2016]. Use of this approach - making quantitative, comparable, systematic national policy data available for analysis to complement outcomes data - would represent an important step toward better monitoring of progress toward the SDGs.

In addition to outcome data, details of policy design are critical to gather on a regular basis in order to go beyond monitoring and to provide national governments with the information needed to structure policies that will help move their countries closer to the targets.

The question of how best to meet the SDGs and their targets is not an easy one. Global reports, like the 2015 Education for All Monitoring Report [UNESCO, 2015], draw conclusions regarding effective strategies based on common findings from a handful of studies of a small number of countries, simultaneous trends or apparent associations, as compared to a rigorous statistical analysis of longitudinal policy and outcome data. National governments and many global intergovernmental and non-governmental organizations such as UNESCO already collect data on the guaranteed minimum income (GMI) outcome indicators. Merging these data with a global source of policy and law indicators would result in valuable additional information on what works while not increasing the burden or cost of monitoring significantly. Furthermore, once in place, this database could be updated regularly with a reasonable level of effort thereby providing countries with historical data with which global monitoring systems could assess the extent of progress over time. Also, with longitudinal, quantitative data more rigorous analysis of the causal impact of policies would be possible.

\section{Conclusion}

The approach to examining pre-primary education provision used in this article gathering of quantitative, comparable, harmonized policy data to be updated over time - when combined with longitudinal outcome data would make it possible to more rigorously analyze the impact of these various aspects of pre-primary education policies on outcomes and provide policymakers with evidence-based recommendations/ guidance on effective policy design. Tracking both policies and outcomes is essential in order to analyze and determine the relative effectiveness of different approaches, thereby providing policymakers with the tools to plan and allocate resources to make optimal choices with respect to achieving the SDGs.

\section{Acknowledgment}

The authors are grateful to the University of California Los Angeles and the World Health Organization for supporting this work. 


\section{References}

Aboud F.E., Hossain K. (2011) The Impact of Preprimary School on Primary School Achievement in Bangladesh. Early Childhood Research Quarterly, vol. 26, no 2, pp. 237-246.

Alderman H., Orazem P., Paterno E. (2001) School Quality, School Cost, and the Public/Private School Choices of Low-Income Households in Pakistan. Journal of Human Resources, vol. 36, no 2, pp. 304-326.

Atabay E., Moreno G., Nandi A., Kranz G., Vincent I., Assi T.M., Winfrey E.V., Earle A., Raub A., Heymann S.J. (2015) Facilitating Working Mothers' Ability to Breastfeed: Global Trends in Guaranteeing Breastfeeding Breaks at Work, 1995-2014. Journal of Human Lactation, vol. 31, no 1, pp. 81-88.

Barnett W.S., Masse L.N. (2007) Comparative Benefit-Cost Analysis of the Abecedarian Program and Its Policy Implications. Economics of Education Review, vol. 26, no 1, pp. 113-125.

Berlinski S., Galiani S., Gertler P. (2009) The Effect of Pre-Primary Education on Primary School Performance. Journal of Public Economics, vol. 93, no 1-2, pp. 219-234.

Berlinski S., Galiani S., Manacorda M. (2008) Giving Children a Better Start: Preschool Attendance and School-Age Profiles. Journal of Public Economics, vol. 92, no 5, pp. 1416-1440.

Britto P.R., Yoshikawa H., van Ravens J., Ponguta L.A., Reyes M., Oh S., Dimaya R., Nieto A.M., Seder R. (2014) Strengthening Systems for Integrated Early Childhood Development Services: A CrossNational Analysis of Governance. Annals of the New York Academy of Sciences, vol. 1308, pp. 245-255.

Burke K., Beegle K. (2004) Why Children Aren't Attending School: The Case of Northwestern Tanzania. Journal of African Economies, vol. 13, no 2, pp. 333-355.

Cassola A., Raub A., Heymann S.J. (2016) Do Constitutions Guarantee Equal Rights Across Socioeconomic Status? A Half Century of Change in the World's Constitutions. Journal of International and Comparative Social Policy, vol. 32, no 3, pp. 235-263.

Conklin A., Ponce N., Frank J., Nandi A., Heymann S.J. (2016) Minimum Wage and Overweight and Obesity in Adult Women: A Multilevel Analysis of Low and Middle Income Countries. PloS One, vol. 11, no 3, p. e0150736.

Cortazar A. (2015) Long-Term Effects of Public Early Childhood Education on Academic Achievement in Chile. Early Childhood Research Quarterly, vol. 32, no 3, pp. 13-22.

Daku M.T. Raub A., Heymann S.J. (2012) Maternal Leave Policies and Vaccination Coverage: A Global Analysis. Social Science \& Medicine, vol. 74, no 2, pp. 120-124.

de Guzman Chorny N., Raub A., Perry N., Vaughan W.E., Looze J., Savage K., Waisath W., Assi T. M., Heymann S.J. (2014) Facilitating Girls' Access to Quality Education: Global Findings on Tuition-Free and Compulsory Education. Policy Brief, World Policy Analysis Center, University of California Los Angeles. Available at: http://worldpolicycenter.org/sites/default/files/WORLD_Policy_Brief_Facilitating_Girls\%E2\%80\%99_Access_to_Quality_Education_2015.pdf.

Deming D. (2009) Early Childhood Intervention and Life-Cycle Skill Development: Evidence from Head Start. American Economic Journal: Applied Economics, vol. 1, no 3, pp. 111-134.

DiGirolamo A.M., Stansbery P., Lungaho M. (2014) Advantages and Challenges of Integration: Opportunities for Integrating Early Childhood Development and Nutrition Programming. Annals of the New York Academy of Sciences, vol. 1308, pp. 46-53.

Dumas C., Lefranc A. (2010) Early Schooling and Later Outcomes: Evidence from Pre-School Extension in France. Thema Working Paper no 7, Centre National de la Recherche Scientifique, Université de Cergy-Pontoise. Available at: http://thema.u-cergy.fr/IMG/documents/2010-07.pdf.

Earle A., Heymann S.J. (2006) A Comparative Analysis of Paid Leave for the Health Needs of Workers and Their Families Around the World. Journal of Comparative Policy Analysis, vol. 8, no 3, pp. 241-257.

Engle P.L., Young M.E., Tamburlini G. (2013) The Role of the Health Sector in Early Childhood Development. Handbook of Early Childhood Development Research and Its Impact on Global Policy (P.R. Britto, P.L. Engle, C.M. Super (eds)). Oxford: Oxford University Press. 
Grantham-McGregor S., Cheung B., Cueto Y., Glewwe S., Richer L., Trupp B., International Child Development Steering Group (2007) Developmental Potential in the First 5 Years for Children in Developing Countries. The Lancet, vol. 369, no 9995, pp. 60-70.

Hajizadeh M., Heymann S.J., Strumpf E., Harper S., Nandi A. (2015) Paid Maternity Leave and Childhood Vaccination Uptake: Longitudinal Evidence from 20 Low- and Middle-income Countries. Social Science \& Medicine, vol. 140, pp. 104-117.

Havnes T., Mogstad M. (2011) No Child Left Behind: Subsidized Child Care and Children's Long-Run Outcomes. American Economic Journal: Economic Policy, vol. 3, no 2, pp. 97-129.

Heckman J.J. (2000) Policies to Foster Human Capital. Research in Economics, vol. 54, no 1, pp. 3-56.

Heckman J.J. (2006) Skill Formation and the Economics of Investing in Disadvantaged Children. Science, vol. 312, no 5782, pp. 1900-1902.

Heymann S.J. (2013) Children's Chances: How Countries Can Move from Surviving to Thriving. Boston: Harvard University Press.

Heymann S.J., McNeill K., Raub A. (2015) Rights Monitoring and Assessment Using Quantitative Indicators of Law and Policy: ICESCR. Human Rights Quarterly, vol. 37, pp. 1071-100.

Heymann S.J., McNeill K., Raub A. (2014a) Assessing Compliance with the CRC: Indicators of Law and Policy in 191 Countries. The International Journal of Children's Rights, vol. 22, no 3, pp. 425-445.

Heymann S.J., Raub A., Cassola A. (2013) Does Prohibiting Child Labor Increase Secondary School Enrolment? Insights from a New Global Dataset. International Journal of Educational Research, vol. 60, pp. $38-45$.

Heymann S.J., Raub A., Cassola A. (2014b) Constitutional Rights to Education and Their Relationship to National Policy and School Enrolment. International Journal of Educational Development, vol. 39, pp. $121-131$.

Hillman A.L., Jenkner E. (2004) User Payments for Basic Education in Low-Income Countries. Helping Countries Develop: The Role of Fiscal Policy (S. Gupta, B. Clements, G. Inchauste (eds)). Washington DC: International Monetary Fund.

Jaramillo A., Tietjen K. (2001) Early Childhood Development in Africa: Can We Do More for Less? Africa Region Human Development Working Paper Series no 22614, The World Bank. Available at: http:// documents.worldbank.org/curated/en/374121468771611619/pdf/multi0page.pdf

Kadzamira E., Rose P. (2003) Can Free Primary Education Meet the Needs of the Poor? Evidence from Malawi. International Journal of Educational Development, vol. 23, pp. 501-516.

Knudsen E.I., Heckman J.J., Cameron J.L., Shonkoff J.P. (2006) Economic, Neuro-Biological and Behavioral Perspectives on Building America's Future Workforce. Proceedings of the National Academy of Sciences, vol. 103, no 27, pp. 10155-10162.

Lesnikowski A., Ford J., Biesbroek R., Berrang-Ford L., Heymann S.J. (2016) National-Level Progress on Adaptation. Nature Climate Change, vol. 6, pp. 261-4.

Martinez S., Naudeau S., Pereira V. (2012) The Promise of Preschool in Africa: A Randomized Impact Evaluation of Early Childhood Development in Rural Mozambique. Impact Evaluation no 001, International Initiative for Impact Evaluation (3ie). Available at: http://www.3ieimpact.org/media/filer public/2013/04/11/3ie_mozambique_ie001.pdf.

Mingat A., Seurat A. (2011) Développement des enfants de 0 à 6 ans et pratiques parentales à Madagascar [Development of Children Aged 0 to 6 and Parenting Practices in Madagascar]. Antananarivo: UNICEF. Available at: https://halshs.archives-ouvertes.fr/halshs-00605037. (In French)

Mtahabwa L., Rao N. (2010) Pre-Primary Education in Tanzania: Observations from Urban and Rural Classrooms. International Journal of Educational Development, vol. 30, no 3, pp. 227-335.

Nandi A., Hajizadeh M., Harper S., Koski A., Strumpf E.C., Heymann S.J. (2016) Increased Duration of Paid Maternity Leave Lowers Infant Mortality in Low- and Middle-Income Countries: A Quasi-experimental Study. PLoS Medicine, vol. 13, no 3, p. e1001985. 
Neuman M.J., Devercelli A.E. (2013) What Matters Most for Early Childhood Development: A Framework Paper. Systems Approach for Better Education Results (SABER) Technical Paper no 5, The World Bank. Available at: https://openknowledge.worldbank.org/handle/10986/20174.

Nielsen H.D. (2009) Moving Toward Free Primary Education: Policy Issues and Implementation Challenges. New York: UNICEF.

Organisation for Economic Co-operation and Development (OECD) (2011) Does Participation in PrePrimary Education Translate into Better Learning Outcomes at School? PISA in Focus. Available at: http://www.oecd-ilibrary.org/education/does-participation-in-pre-primary-education-translate-intobetter-learning-outcomes-at-school_5k9h362tpvxp-en.

Princeton University (2006) Free to Learn: A Rights Based Approach to Universal Primary Education in Kenya. Princeton University: Woodrow Wilson School of Public and International Affairs.

Quamruzzaman A., Mendoza J.M., Heymann S.J., Kaufman J.S., Nandi A. (2014) Are Tuition-Free Primary Education Policies Associated with Lower Infant and Neonatal Mortality in Low- and MiddleIncome Countries? Social Science \& Medicine, vol. 120, pp. 153-159.

Raub A., Latz I., Sprague A., Stein M.A., Heymann S.J. (2016) Constitutional Rights of Persons with Disabilities: An Analysis of 193 National Constitutions. Harvard Human Rights Journal, vol. 29, pp. 20340.

Reynolds A.J., Temple J.A., Robertson D.L., Mann E.A. (2002) Age 21 Cost-Benefit Analysis of the Title I Chicago Child-Parent Centers. Educational Evaluation and Policy Analysis, vol. 24, pp. 267-303.

Save the Children (2003) What's the Difference? An ECD Impact Study from Nepal. Children's Environments Research Group, UNICEF. Available at: https://www.unicef.org/media/files/Nepal_2003 ECD_Impact_Studty.pdf.

Sayre R.K., Devercelli A.E., Neuman M.J., Wodon Q. (2014) Investing in Early Childhood Development: Review of the World Bank's Recent Experience. World Bank Studies, The World Bank Group. Available at: http://documents.worldbank.org/curated/en/664071468124463563/Investing-in-earlychildhood-development-review-of-the-World-Banks-recent-experience.

Schliwen A., Earle A., Hayes J., Heymann S.J. (2011) The Administration and Financing of Paid Sick Leave. International Labour Review, vol. 150, no 1-2, pp. 43-62.

Schweinhart L.J., Montie J., Xiang Z., Barnett W.S., Belfield C.R., Nores M. (2005) Lifetime Effects: The High/Scope Perry Preschool Study Through Age 40. Ypsilanti: High/Scope Press.

Sheridan S., Giota J., Han Y.-M., Kwon J.-Y. (2009) A Cross-Cultural Study of Preschool Quality in South Korea and Sweden: ECERS Evaluations. Early Childhood Research Quarterly, vol. 24, no 2, pp. 142-156.

Shonkoff J.P., Phillips D.A. (eds) (2000) From Neurons to Neighborhoods: The Science of Early Child Development. Washington DC: National Academy Press.

Sustainable Development Solutions Network (2015) Indicators and a Monitoring Framework for the Sustainable Development Goals: Launching the Data Revolution for the SDGs. Report to the SecretaryGeneral of the United Nations by the Leadership Council of the Sustainable Development Solutions Network. Available at: http://unsdsn.org/wp-content/uploads/2015/05/FINAL-SDSN-Indicator-Report-WEB.pdf.

United Nations (UN) (2015) Transforming Our World: The 2030 Agenda for Sustainable Development. Resolution Adopted by the General Assembly on 25 September 2015. Available at: http://www.un.org/ga/ search/view_doc.asp?symbol=A/RES/70/1\&Lang=E.

United Nations Educational, Scientific and Cultural Organization (UNESCO) (2012) International Standard Classification of Education (ISCED) 2011. UNESCO Institute for Statistics. Available at: http://uis.unesco.org/sites/default/files/documents/international-standard-classification-of-education-isced-2011-en.pdf.

United Nations Educational, Scientific and Cultural Organization (UNESCO) (2015) Education for All 2000-2015: Achievements and Challenges. Education for All (EFA) Global Monitoring Report. Avai- 
lable at: http://en.unesco.org/gem-report/report/2015/education-all-2000-2015-achievements-andchallenges\#sthash.pBSt01Rk.dpbs.

Vargas-Baron E. (2015) Policies on Early Childhood Care and Education: Their Evolution and Some Impacts. Background paper prepared for the Education for All (EFA) Global Monitoring Report 2015. Available at: http://unesdoc.unesco.org/images/0023/002324/232459e.pdf.

World Bank (2001) Brazil Early Child Development: A Focus on the Impact of Preschools. Report no 22841-BR, Human Development Department, Brazil Country Management Unit, Latin America and the Caribbean Region. Available at: http://documents.worldbank.org/curated/en/408291468769743509/ pdf/multi0page.pdf

World Bank (2013) SABER Early Childhood Development Country Report: Colombia. Systems Approach for Better Education Results (SABER) Country Report. Available at: http://documents.worldbank.org/curated/en/574501468028793407/pdf/799290WP0SABER0Box0379795B00PUBLIC0.pdf.

World Bank (2016) How Does the World Bank Classify Indicators? World Development Indicators Data. Available at: https://datahelpdesk.worldbank.org/knowledgebase/articles/378834-how-does-the-worldbank-classify-countries.

Yoshikawa H., Kabay S.B. (2015) The Evidence Base on Early Childhood Care and Education in Global Contexts. Background paper prepared for the Education for All (EFA) Global Monitoring Report 2015. Available at: http://unesdoc.unesco.org/images/0023/002324/232456e.pdf.

\section{Appendix A: Summary Statistics of Variables Used in Regression Analyses ( $\mathrm{N}=124)$}

\begin{tabular}{|l|c|c|c|c|c|}
\hline \multicolumn{1}{|c|}{ Variable name } & N & Mean & $\begin{array}{c}\text { Standard } \\
\text { deviation }\end{array}$ & Minimum & Maximum \\
\hline Dependent & & & & & \\
\hline $\begin{array}{l}\text { Pre-primary education net enrolment } \\
\text { rates, 2011 (in \%) }\end{array}$ & 124 & 55.33 & 30.40 & 1.04 & 99.63 \\
\hline Independent & 124 & 0.49 & 0.50 & 0 & 1 \\
\hline $\begin{array}{l}\text { Is pre-primary education free? } \\
\text { (yes=1) }\end{array}$ & 124 & 8.80 & 1.53 & 5.48 & 11.97 \\
\hline Control & 124 & 58.17 & 23.20 & 10.91 & 98.81 \\
\hline $\begin{array}{l}\text { Logarithm of per capita GDP } \\
\text { (in \$1,000) }\end{array}$ & $\begin{array}{l}\text { Percent of population living in urban } \\
\text { area (in \%) }\end{array}$ & & & & \\
\hline
\end{tabular}

Note: Sample size reduced from 166 to 124 due to data availability for independent and control variables.

Source: Compiled by the authors. 


\title{
Мониторинг прогресса в достижении ЦУР ООН по дошкольному образованию: важный шаг для обеспечения справедливости и устойчивости национальных экономик ${ }^{1}$
}

\author{
Н.М. Милованцева, А. Ёрл, Д. Хейман
}

\begin{abstract}
Милованцева Наталья Михайловна - PhD, доцент факультета мировой экономики и мировой политики Национального исследовательского университета «Высшая школа экономики»; Российская Федерация, 101000, Москва, ул. Мясницкая, д. 20; E-mail: nmilovantseva@hse.ru
\end{abstract}

Ёрл Алисон - PhD, старший научный сотрудник Центра анализа мировой политики Калифорнийского университета в Лос-Анджелесе (UCLA); University of California, Los Angeles, 621 Charles E. Young Dr. South, Los Angeles, CA 90095 USA; E-mail: aearle@ph.ucla.edu

Хейман Джёди - MD, PhD, член национальной медицинской академии США и Канадской академии медицинских наук, основатель и директор Центра анализа мировой политики и профессор школ: здравоохранения им. Филдинга, общественных наук им. Ласкина и медицины им. Геффена Калифорнийского университета в Лос-Анджелесе (UCLA); University of California, Los Angeles, 621 Charles E. Young Dr. South, Los Angeles, CA 90095 USA; E-mail: jody.heymann@ph.ucla.edu

Несмотря на широкий консенсус международных организаций в отношении важности здорового развития детей в раннем возрасте, мониторинг национальных действий по обеспечению дошкольного образования ограничен. В настоящей статье представлен количественный подход к мониторингу мирового прогресса по достижению задачи 4.2 Целей устойчивого развития (ЦУР) Организации Объединенных Наций (ООН): «...обеспечить, чтобы все девочки и мальчики имели доступ к качественным системам развития, ухода и дошкольного обучения детей младшего возраста». Мы использовали строгий подход для создания новой количественной глобальной базы данных сопоставимых показателей политики, которые характеризуют предоставление национального дошкольного образования для 86\% государств - членов ООН. Этот набор данных был проанализирован для изучения глобального неравенства в обеспечении всеобщего дошкольного образования. Мы обнаружили, что $43 \%$ всех стран и всего $3 \%$ стран с низким уровнем дохода обеспечивают бесплатное дошкольное образование. Менее 25\% стран предлагают бесплатное дошкольное образование в течение двух или более лет. Это резко контрастирует с начальным образованием, которое предоставляется бесплатно в 96\% стран. Чтобы проиллюстрировать, как эти данные могут использоваться для изучения взаимосвязей между политикой и ее результатами, мы использовали регрессионный анализ. Дополнительный сбор глобальных данных о качестве дошкольного образования еще более активизирует усилия по мониторингу политики, которая играет ключевую роль в достижении задачи 4.2, и окажет поддержку достижению ЦУР ООН в области образования.

Ключевые слова: цели устойчивого развития; количественные данные о политике; глобальное неравенство в образовании; политика в области образования; сравнительный анализ политики

Для цитирования: Милованцева Н.М., Ёрл А., Хейман Д. (2018) Мониторинг прогресса в достижении ЦУР $\mathrm{OOH}$ по дошкольному образованию: важный шаг для обеспечения справедливости и устойчивости национальных экономик // Вестник международных организаций. Т. 13. № 4. С. 137-158 (на русском и английском языках). DOI: 10.17323/1996-7845-2018-04-06.

\footnotetext{
${ }^{1}$ Статья поступила в редакцию в октябре 2017 г.
} 


\section{Источники}

Aboud F.E., Hossain K. (2011) The Impact of Preprimary School on Primary School Achievement in Bangladesh // Early Childhood Research Quarterly. T. 26. No. 2. P. 237-46.

Alderman H., Orazem P., Paterno E. (2001) School Quality, School Cost, and the Public / Private School Choices of Low-Income Households in Pakistan // Journal of Human Resources. Vol. 36. No. 2. P. 304-26.

Atabay E., Moreno G., Nandi A., Kranz G., Vincent I., Assi T.M., Winfrey E.V., Earle A., Raub A., Heymann S.J. (2015) Facilitating Working Mothers' Ability to Breastfeed: Global Trends in Guaranteeing Breastfeeding Breaks at Work, 1995-2014 // Journal of Human Lactation. Vol. 31. No. 1. P. 81-8.

Barnett W.S., Masse L.N. (2007) Comparative Benefit-Cost Analysis of the Abecedarian Program and Its Policy Implications // Economics of Education Review. Vol. 26. No. 1. P. 113-25.

Berlinski S., Galiani S., Gertler P. (2009) The Effect of Pre-Primary Education on Primary School Performance // Journal of Public Economics. Vol. 93. No. 1-2. P. 219-34.

Berlinski S., Galiani S., Manacorda M. (2008) Giving Children a Better Start: Preschool Attendance and School-Age Profiles // Journal of Public Economics. Vol. 92. No. 5. P. 1416-40.

Britto P.R., Yoshikawa H., van Ravens J., Ponguta L.A., Reyes M., Oh S., Dimaya R., Nieto A.M., Seder R. (2014) Strengthening Systems for Integrated Early Childhood Development Services: A Cross-National Analysis of Governance // Annals of the New York Academy of Sciences. Vol. 1308. P. 245-55.

Burke K., Beegle K. (2004) Why Children Aren't Attending School: The Case of Northwestern Tanzania // Journal of African Economies. Vol. 13. No. 2. P. 333-55.

Cassola A., Raub A., Heymann S.J. (2016) Do Constitutions Guarantee Equal Rights Across Socioeconomic Status? A Half Century of Change in the World's Constitutions // Journal of International and Comparative Social Policy. Vol. 32. No. 3. P. 235-63.

Conklin A., Ponce N., Frank J., Nandi A., Heymann S.J. (2016) Minimum Wage and Overweight and Obesity in Adult Women: A Multilevel Analysis of Low and Middle Income Countries // PloS One. Vol. 11. No. 3. P. e0150736.

Cortazar A. (2015) Long-Term Effects of Public Early Childhood Education on Academic Achievement in Chile // Early Childhood Research Quarterly. Vol. 32. No. 3. P. 13-22.

Daku M.T. Raub A., Heymann S.J. (2012) Maternal Leave Policies and Vaccination Coverage: A Global Analysis // Social Science \& Medicine. Vol. 74. No. 2. P. 120-4.

de Guzman Chorny N., Raub A., Perry N., Vaughan W.E., Looze J., Savage K., Waisath W., Assi T.M., Heymann S.J. (2014) Facilitating Girls Access to Quality Education: Global Findings on Tuition-Free and Compulsory Education. Policy Brief, World Policy Analysis Center, University of California Los Angeles. Режим доступа: http://worldpolicycenter.org/sites/default/files/WORLD_Policy_Brief_Facilitating Girls\%E2\%80\%99_Access_to_Quality_Education_2015.pdf (дата обращения: 30.10.2018).

Deming D. (2009) Early Childhood Intervention and Life-Cycle Skill Development: Evidence from Head Start // American Economic Journal: Applied Economics. Vol. 1. No. 3. P. 111-34.

Di Girolamo A. M., Stansbery P., Lungaho M. (2014) Advantages and Challenges of Integration: Opportunities for Integrating Early Childhood Development and Nutrition Programming // Annals of the New York Academy of Sciences. Vol. 1308. P. 46-53.

Dumas C., Lefranc A. (2010) Early Schooling and Later Outcomes: Evidence from Pre-School Extension in France. Thema Working Paper no 7, Centre National de la Recherche Scientifique, Université de Cergy-Pontoise. Режим доступа: http://thema.u-cergy.fr/IMG/documents/2010-07.pdf (дата обращения: 30.10.2018).

Earle A., Heymann S. J. (2006) A Comparative Analysis of Paid Leave for the Health Needs of Workers and Their Families Around the World // Journal of Comparative Policy Analysis. Vol. 8. No. 3. P. 241-57.

Engle P.L., Young M.E., Tamburlini G. (2013) The Role of the Health Sector in Early Childhood Development. Handbook of Early Childhood Development Research and Its Impact on Global Policy (P.R. Britto, P.L. Engle, C.M. Super (eds)). Oxford: Oxford University Press. 
Grantham-McGregor S., Cheung B., Cueto Y., Glewwe S., Richer L., Trupp B., International Child Development Steering Group (2007) Developmental Potential in the First 5 Years for Children in Developing Countries // The Lancet. Vol. 369. No. 9995. P. 60-70.

Hajizadeh M., Heymann S.J., Strumpf E., Harper S., Nandi A. (2015) Paid Maternity Leave and Childhood Vaccination Uptake: Longitudinal Evidence from 20 Low- and Middle-income Countries // Social Science \& Medicine. Vol. 140. P. 104-17.

Havnes T., Mogstad M. (2011) No Child Left Behind: Subsidized Child Care and Children's Long-Run Outcomes // American Economic Journal: Economic Policy. Vol. 3. No. 2. P. 97-129.

Heckman J. J. (2000) Policies to Foster Human Capital // Research in Economics. Vol. 54. No. 1. P. 3-56.

Heckman J.J. (2006) Skill Formation and the Economics of Investing in Disadvantaged Children // Science. Vol. 312. No. 5782. P. 1900-02.

Heymann S.J. (2013) Children's Chances: How Countries Can Move from Surviving to Thriving. Boston: Harvard University Press.

Heymann S.J., McNeill K., Raub A. (2015) Rights Monitoring and Assessment Using Quantitative Indicators of Law and Policy: ICESCR // Human Rights Quarterly. Vol. 37. P. 1071-100.

Heymann S.J., McNeill K., Raub A. (2014a) Assessing Compliance with the CRC: Indicators of Law and Policy in 191 Countries // The International Journal of Children's Rights. Vol. 22. No. 3. P. 425-45.

Heymann S.J., Raub A., Cassola A. (2013) Does Prohibiting Child Labor Increase Secondary School Enrolment? Insights from a New Global Dataset // International Journal of Educational Research. Vol. 60. P. 38-45.

Heymann S.J., Raub A., Cassola A. (2014b) Constitutional Rights to Education and Their Relationship to National Policy and School Enrolment // International Journal of Educational Development. Vol. 39. P. 121-31.

Hillman A.L., Jenkner E. (2004) User Payments for Basic Education in Low-Income Countries. Helping Countries Develop: The Role of Fiscal Policy (S. Gupta, B. Clements, G. Inchauste (ред)). Washington DC: International Monetary Fund.

Jaramillo A., Tietjen K. (2001) Early Childhood Development in Africa: Can We Do More for Less? Africa Region Human Development Working Paper Series no 22614, the World Bank. Режим доступа: http://documents.worldbank.org/curated/en/374121468771611619/pdf/multi0page.pdf (дата обращения: 30.10.2018).

Kadzamira E., Rose P. (2003) Can Free Primary Education Meet the Needs of the Poor? Evidence from Malawi // International Journal of Educational Development. Vol. 23. P. 501-16.

Knudsen E.I., Heckman J.J., Cameron J.L., Shonkoff J.P. (2006) Economic, Neuro-Biological and Behavioral Perspectives on Building America's Future Workforce // Proceedings of the National Academy of Sciences. Vol. 103 No. 27. P. 10155-62.

Lesnikowski A., Ford J., Biesbroek R., Berrang-Ford L., Heymann S.J. (2016) National-Level Progress on Adaptation // Nature Climate Change. Vol. 6. P. 261-4.

Martinez S., Naudeau S., Pereira V. (2012) The Promise of Preschool in Africa: A Randomized Impact Evaluation of Early Childhood Development in Rural Mozambique. Impact Evaluation no 001, International Initiative for Impact Evaluation (3ie). Режим доступа: http://www.3ieimpact.org/media/filer_public/2013/04/11/3ie_ mozambique_ie001.pdf (дата обращения: 30.10.2018).

Mingat A., Seurat A. (2011) Développement des enfants de 0 à 6 ans et pratiques parentales à Madagascar [Development of Children Aged 0 to 6 and Parenting Practices in Madagascar]. Antananarivo: UNICEF. Режим доступа: https://halshs.archives-ouvertes.fr/halshs-00605037 (дата обращения: 30.10.2018).

Mtahabwa L., Rao N. (2010) Pre-Primary Education in Tanzania: Observations from Urban and Rural Classrooms // International Journal of Educational Development. Vol. 30. No. 3. P. 227-35.

Nandi A., Hajizadeh M., Harper S., Koski A., Strumpf E.C., Heymann S.J. (2016) Increased Duration of Paid Maternity Leave Lowers Infant Mortality in Low- and Middle-Income Countries: A Quasi-experimental Study // PLoS Medicine. Vol. 13. No. 3. P. e1001985.

Neuman M.J., Devercelli A.E. (2013) What Matters Most for Early Childhood Development: A Framework Paper. Systems Approach for Better Education Results (SABER) Technical Paper no 5, The World Bank. Режим доступа: https://openknowledge.worldbank.org/handle/10986/20174 (дата обращения: 30.10.2018). 
Nielsen H.D. (2009) Moving Toward Free Primary Education: Policy Issues and Implementation Challenges. New York: UNICEF.

Organisation for Economic Co-operation and Development (OECD) (2011) Does Participation in Pre-Primary Education Translate into Better Learning Outcomes at School? PISA in Focus. Режим доступа: http:// www.oecd-ilibrary.org/education/does-participation-in-pre-primary-education-translate-into-better-learning-outcomes-at-school_5k9h362tpvxp-en (дата обращения: 30.10.2018).

Princeton University (2006) Free to Learn: A Rights Based Approach to Universal Primary Education in Kenya. Princeton University: Woodrow Wilson School of Public and International Affairs.

Quamruzzaman A., Mendoza J.M., Heymann S.J., Kaufman J.S., Nandi A. (2014) Are Tuition-Free Primary Education Policies Associated with Lower Infant and Neonatal Mortality in Low- and Middle-Income Countries? // Social Science \& Medicine. Vol. 120. P. 153-9.

Raub A., Latz I., Sprague A., Stein M.A., Heymann S.J. (2016) Constitutional Rights of Persons with Disabilities: An Analysis of 193 National Constitutions // Harvard Human Rights Journal. Vol. 29. P. 203-40.

Reynolds A.J., Temple J.A., Robertson D.L., Mann E.A. (2002) Age 21 Cost-Benefit Analysis of the Title I Chicago Child-Parent Centers // Educational Evaluation and Policy Analysis. Vol. 24. P. 267-303.

Save the Children (2003) What's the Difference? An ECD Impact Study from Nepal. Children's Environments Research Group, UNICEF. Режим доступа: https://www.unicef.org/media/files/Nepal_2003_ECD_Impact_Studty.pdf (дата обращения: 30.10.2018).

Sayre R.K., Devercelli A.E., Neuman M.J., Wodon Q. (2014) Investing in Early Childhood Development: Review of the World Bank's Recent Experience. World Bank Studies, The World Bank Group. Режим доступа: http://documents.worldbank.org/curated/en/664071468124463563/Investing-in-early-childhood-development-review-of-the-World-Banks-recent-experience (дата обращения: 30.10.2018).

Schliwen A., Earle A., Hayes J., Heymann S.J. (2011) The Administration and Financing of Paid Sick Leave // International Labour Review. Vol. 150. No. 1-2. P. 43-62.

Schweinhart L.J., Montie J., Xiang Z., Barnett W.S., Belfield C.R., Nores M. (2005) Lifetime Effects: The High/Scope Perry Preschool Study Through Age 40. Ypsilanti: High/Scope Press.

Sheridan S., Giota J., Han Y.-M., Kwon J.-Y. (2009) A Cross-Cultural Study of Preschool Quality in South Korea and Sweden: ECERS Evaluations // Early Childhood Research Quarterly. Vol. 24. No. 2. P. 142-56.

Shonkoff J.P., Phillips D.A. (eds) (2000) From Neurons to Neighborhoods: The Science of Early Child Development. Washington DC: National Academy Press.

Sustainable Development Solutions Network (2015) Indicators and a Monitoring Framework for the Sustainable Development Goals: Launching the Data Revolution for the SDGs. Report to the Secretary-General of the United Nations by the Leadership Council of the Sustainable Development Solutions Network. Режим доступа: http://unsdsn.org/wp-content/uploads/2015/05/FINAL-SDSN-Indicator-Report-WEB.pdf (дата обращения: 30.10 .2018$)$.

United Nations (UN) (2015) Transforming Our World: The 2030 Agenda for Sustainable Development. Resolution Adopted by the General Assembly on 25 September 2015. Режим доступа: http://www.un.org/ga/ search/view_doc.asp?symbol=A/RES/70/1\&Lang=E (дата обращения: 30.10.2018).

United Nations Educational, Scientific and Cultural Organization (UNESCO) (2012) International Standard Classification of Education (ISCED) 2011. UNESCO Institute for Statistics. Режим доступа: http://uis.unesco.org/sites/default/files/documents/international-standard-classification-of-education-isced-2011-en.pdf (дата обращения: 30.10.2018).

United Nations Educational, Scientific and Cultural Organization (UNESCO) (2015) Education for All 2000-2015: Achievements and Challenges. Education for All (EFA) Global Monitoring Report. Режим доступа: $\quad$ http://en.unesco.org/gem-report/report/2015/education-all-2000-2015-achievements-andchallenges\#sthash.pBSt01 Rk.dpbs (дата обращения: 30.10.2018).

Vargas-Baron E. (2015) Policies on Early Childhood Care and Education: Their Evolution and Some Impacts. Background paper prepared for the Education for All (EFA) Global Monitoring Report 2015. Режим доступа: http://unesdoc.unesco.org/images/0023/002324/232459e.pdf (дата обращения: 30.10.2018).

World Bank (2001) Brazil Early Child Development: A Focus on the Impact of Preschools. Report no 22841BR, Human Development Department, Brazil Country Management Unit, Latin America and the Carib- 
bean Region. Режим доступа: http://documents.worldbank.org/curated/en/408291468769743509/pdf/multi0page.pdf (дата обрашения: 30.10.2018).

World Bank (2013) SABER Early Childhood Development Country Report: Colombia. Systems Approach for Better Education Results (SABER) Country Report. Режим доступа: http://documents.worldbank.org/curated/en/574501468028793407/pdf/799290WP0SABER0Box0379795B00PUBLIC0.pdf (дата обращения: 30.10.2018).

World Bank (2016) How Does the World Bank Classify Indicators? World Development Indicators Data. Режим доступа: https://datahelpdesk.worldbank.org/knowledgebase/articles/378834-how-does-the-worldbank-classify-countries (дата обрашения: 30.10.2018).

Yoshikawa H., Kabay S.B. (2015) The Evidence Base on Early Childhood Care and Education in Global Contexts. Background paper prepared for the Education for All (EFA) Global Monitoring Report 2015. Режим доступа: http://unesdoc.unesco.org/images/0023/002324/232456e.pdf (дата обращения: 30.10.2018). 